U. S. DEPARTMENT OF AGRICULTURE, BUREAU OF ANIMAL INDUSTRY.-CIRCULAR 170.

A. D. MELVIN, ChIEF OF BUREAU.

\title{
THE EXTRA COST OF PRODUCING
}

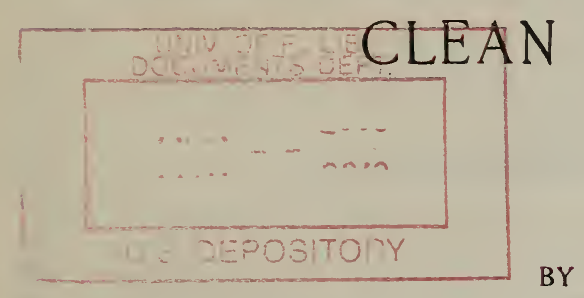

GEORGE M. WHITAKER,

In Charge of Work Relating to Market Milk, Dairy Division.

[Reprinted from the Twenty-sixth Annual Report of the Bureau of Animal Industry (1909).]

WASHINGTON:

GOVERNMENT PRINTING OFFICE.

1911. 


\section{CONTENTS.}

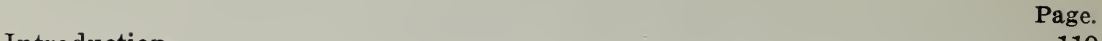

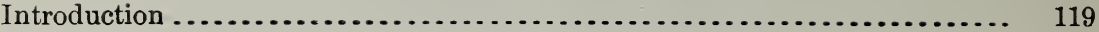

Dairy score card ................................................ $\quad 120$

.The requirements of modern health regulations....................... 121

The standard of production which every dairyman should reach........... 122

The cows ................................................... 122

The stable ................................................ 122

Cleanliness of milker, utensils, etc............................ 123

Some "horrible examples" of dairies............................. 124

Improvements involving added expense to the dairyman............... 124

Clean cows and sanitary stable ................................ 124

The milk room ........................................... 126

Utensils, equipment, etc.................................... 126

Summary of conditions involving added expense.................. 128

General summary ................................................... 129

\section{L L USTRATI 0 NS.}

Plate IV. Dirty barnyards, wasteful of manure, and increasing expenses of keeping cows clean .....................................

V. Fig. 1. - Stable with insufficient light and ventilation. Fig. 2.-A stable that is difficult and expensive to keep clean.............

VI. Fig. 1.-Sediment in bottom of bottle of milk. Fig. 2.-A milk house favorable for dirt and odors

VII. Fig. 1.-Milk cans exposed to dirt and flies. Fig. 2.-An inexpensive cement milk house.............................

Fı. 3. Open and hooded milk pails............................... 


\title{
THE EXTRA COST OF PRODUCING CLEAN MILK.
}

\author{
By George M. Whitaker, \\ In Charge of Work relating to Market Milk, Dairy Division.
}

\section{INTRODUCTION.}

New methods are always more or less unpopular. Every business and profession has its conservative element which looks with suspicion at new ideas, especially those which threaten to jolt one out of well-established ruts. For instance, many of the old-school surgeons were skeptical about bacteriology and the aseptic methods of operating, which are now in vogue with such wonderful results. Milk producers have the same traits of human nature as other people, and many of them have been skeptical as to the utility of the newer ideas about sanitary milk which have caused them some inconvenience and expense.

Unfortunately, the movement for cleaner milk happened to be coincident with a marked increase in the cost of production, due to feed and labor problems, and a failure to get a corresponding increase in price. The feeling of dissatisfaction with prevailing economic conditions has had a tendency to develop hostility to the latest phases of milk production.

This natural feeling of irritation has been intensified in some instances by dairy inspectors who have lacked tact and good judgment; their arbitrary bearing, their ignorance, or their lack of sympathy have done much to make the movement unpopular. In some instances, also, this feeling has been increased by persons who from various motives have misrepresented modern requirements by exaggeration, ridicule, misleading half truths, or plausible generalities.

In view of this situation there seems to be need of accurate statements as to precisely what modern sanitary milk means and what extra cost it imposes on the dairyman. In considering the added cost of production due to this agitation we make the dairy score card the basis of our discussion, because it includes in convenient tabular form practically all of the points which need to be considered. This score card is in common use and is indorsed by many leading dairy and health authorities. 


\section{The card is as follows:}

\section{DAIRY SCORE CARD.}

Score for equipment_._._._._- + Score for methods_____

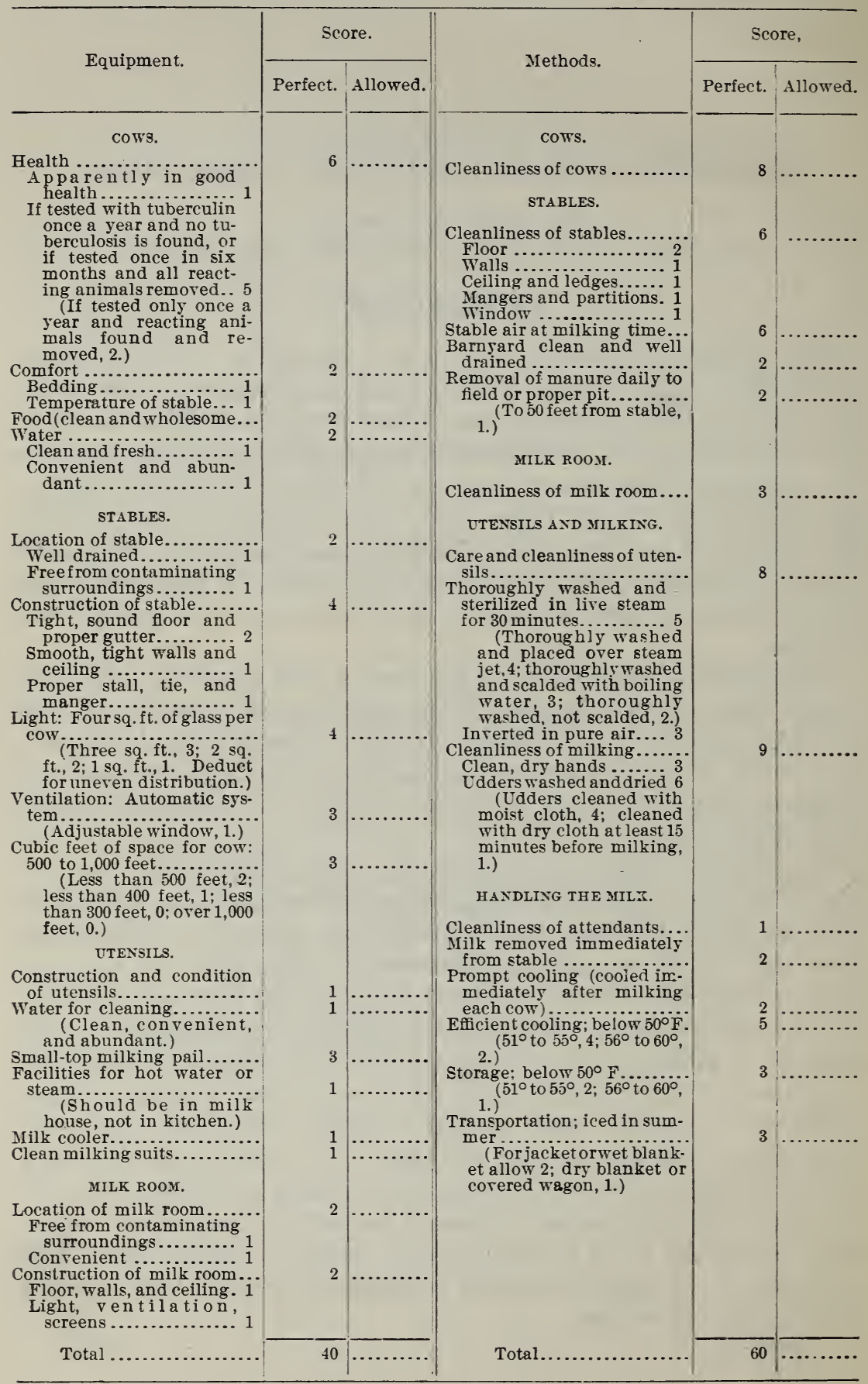


The different items on the score card are not requirements, but things that must be considered in the production of milk; and the producer whose dairy is inspected is rated on each item according to the relation which its condition bears to perfect conditions. An advantage of the score-card system of inspection is that its statements are made in mathematical terms rather than by the vague, indefinite words "excellent," "good," "fair," "medium," and "bad." Such words mean very little, and each one may include a wide variety of conditions. The perfect dairy would score 100, and one superlatively excellent would come very close to that, say, 97 to 99 . Some dairies run by wealthy gentlemen for pleasure rather than profit, just as they indulge in yachting or automobiling, will reach a score in the nineties-possibly as high as 99 . Some certified-milk dairies can be given a similar score. The better class of what may be called common dairies are usually found in the seventies, and such dairies can, as a rule, be called reasonably satisfactory from the sanitary standpoint. In other words, it is not asked or expected that anyone will reach perfection; a dairy may be rated 25 to 30 points below perfect and yet hare reasonably safe and satisfactory conditions. Barring a few exceptions, modern sanitary requirements are practically met by a score of 70 or thereabouts, although it is hoped that the ambitious dairyman will strive to get into the eighties or above, and that he will find appreciative consumers who will be willing to pay an extra price for milk produced under such superior circumstances.

\section{THE REQUIREMENTS OF MODERN HEALTH REGULATIONS.}

What added burdens do modern health regulations impose on the market milk producer? The answer to this question will vary much with different individuals and different conditions. Where the latter are so bad as to be rated as low as 20 the cost of reaching a score of 70 will, of course, be more than where one can start with respectable mediocrity, represented by 50 , for instance; in other words, the longer the journey the greater the expense. But it should be remembered that in the change from a score of 20 to one of 70 much of the expense should be charged to ordinary decency and not to modern ideas regarding clean milk. We presume that no one, no matter how much of a skeptic he may be concerning milk bacteriology, would openly defend a condition so bad as to deserve a rating no better than 20. In such a case only an insignificant minority not worth considering would criticise a peremptory demand for radical and even expensive changes. If the expense should prove to be beyond the means of the producer there might be sympathy for him, but no criticism of the health officer who put him out of business. Indeed, conditions below 35 are so bad as to call for and justify a peremptory order for improvement. 
Scores ranging from about 35 to 60 represent conditions that demand improvement. In such cases modern official milk inspection may properly interfere, although these conditions may have been hitherto regarded as satisfactory.

Upon those milk producers who already have conditions which may be expressed by about 70 or above, the newer milk ordinances impose no additional burden. Such producers are, however, voluntarily assuming an expense which is not incurred by the slovenly producer.

\section{THE STANDARD OF PRODUCTION WHICH EVERY DAIRYMAN SHOULD REACH.}

At the outset let us consider what every milk producer ought to do as a matter of decency or as an unquestioned incident of his business. It must be recognized that a certain amount of equipment is essential. There must be healthy cows, wholesome feed, plenty of clean and fresh water, and comfortable quarters. This gives 12 points on the score card to start with.

THE COWS.

In cleanliness the cows vary widely, ranging from the neglected animal with manure-plastered flanks and udders to the cow carefully groomed every day. Grooming costs money, and is not required, though there is more reason for the daily grooming of an animal that produces human food than of one that hauls a manure spreader or garbage wagon. Custom, however, demands that a horse be kept clean, whether it performs menial tasks or hauls the carriage of some person of wealth.

To raise the score for cleanliness of cattle from zero to 6.5 or 7 requires expense for bedding, for prompt removal of manure, for daily brushing the cows when they are housed, for clipping the long hairs about the udder, and for shortening the switch of the tail if it drags in the manure. But no one would defend the manure-coated cow, and an animal should be at least half clean before the modern health officer can be charged with adding to the expense of maintaining the dairy. This partial cleaning allows 4 points, which, added to the 12 noted above, gives us 16 .

THE STABLE.

A.proper stable is a subject that is much misunderstood and greatly misrepresented. The stable must be so located, constructed, and maintained as to promote the health of the animals and the cleanliness of the product. Many poorly constructed stables are fairly satisfactory when kept clean, and much good milk is being produced in such places by the use of proper methods. But for the present we 
will consider only light and ventilation. If the stable is poorly lighted the expense of sawing a few holes and putting in sash is so infinitesimal (except in basement stables) as to deserve no consideration. The King system of ventilation-which is the system now most prominently before the public-gives good results when properly installed. This adds to the expense, but a good substitute can be found in windows swinging in so that the fresh air is admitted at the top of the sash, over the cows' bodies. This arrangement will cause no appreciable expense. Estimating light at three-fourths of perfect and ventilation at two-thirds of perfect adds ( 3 plus 2) 5 points to our previous estimate of 16 , giving 21 in all so far.

For cleanliness of stable and purity of stable air at milking time 12 points are allowed on the score card. The most vigorous critic of modern sanitary requirements would not defend a place so bad as to deserve no credit for cleanliness. Twò whitewashings a year will add so little to the expense as to be unnoticeable at the end of the year. Feeding hay or ensilage after milking instead of before adds nothing to the expense of production, but results in better milk and may add to the score. We may safely assume that ordinary decency should call for at least half-way cleanliness-6 points, which brings the score to 27 .

The daily removal of manure to a field or proper pit may add somewhat to the expense, but more than the added cost will be returned in the saving of plant food. The 2 points possible to gain here is no added burden on milk production, but an actual economy. Our hypothetical score is now 29.

CLEANLINESS OF MILIKER, UTENSILS, ETC.

Clean milking suits are a bugbear in some localities and have been ridiculed as an unnecessary and faddish item of outlay. The writer found a New England dairyman who while milking wore clean, though not white, overalls and jumper. When they became somewhat soiled they were used for ordinary farm work and clean ones were taken to wear when milking. Thus clean suits were always in use when milking, with no extra expense except the time required to make the changes. This allows 1 point on the score card.

Inverting the utensils in pure air so that they may drain, dry, and be aired, without opportunity for dust to fall into them or probability of contact with flies, gives the producer 3 points and can not add a penny to the cost of production. (Frequently one sees cans and pails containing a few spoonfuls of milky water standing upright and gathering dust and flies.) Total score at present, 33.

The thorough washing of utensils even when they are not scalded gives 2 points on the score card, which should not be charged to the 
added cost of production. The thorough washing of all utensils ought to be considered an unquestioned and necessary incident to milk production.

Milking with clean, dry hands costs nothing and is deemed so good dairy practice as to be given 3 points. This brings the score to 38 .

At least 1 point can be secured without added expense for fairly prompt removal of milk from barn, and one more for covering the cans in transit. Promptness of cooling ( 2 points) is not an expense, for if the milk is cooled at all the expense is the same at one time as another.

Here, then, is a score of 42 , which can be considered a natural and necessary incident of milk production, with nothing allowed as yet for construction of barn and milk room, for utensils, for cooling milk, and for cleaning the cows' udders. Nearly all producers are entitled to some credit for these items, a credit which they would regard as no added burden incident to the newer requirements.

\section{SOME " HORRIBLE EXAMPLES" OF DAIRIES.}

A score of at least 42 to 45 should therefore be the lowest rating of very ordinary dairies and a prerequisite for selling milk. Let us compare this with a few actual figures. The first scoring of the dairies supplying the District of Columbia with milk averaged 43.44; 89 were in the twenties, and 224 in the thirties. The condition of dairies supplying a southern city inspected in 1910 is shown by scores ranging from $2 \check{5}$ to 30 . An investigation of the Chicago supply showed 12 per cent of the dairies in the twenties and 35 per cent in the thirties, with an a verage of 40.20 . The score of the dairies of a Colorado city a veraged about 40 , and of a New Hampshire city 35 to 40.

\section{IMPROVEMENTS INVOLVING ADDEDD EXPENSE TO THE DAIRYMAN.}

Let us now turn back to the score card to consider items passed over or receiving a low estimate, where added expense would unquestionably be incurred in effecting improrement.

CLEAN COWS AND SANITARY STABLE.

For cleanliness of cattle an allowance of 4 points was previously made-too low for a good score; five minutes per cow per day would raise the score from 4 to 7 .

In regard to the stable, much criticism and misunderstanding has arisen. Some critics intimate that modern milk inspection is only a cement-floor propaganda. One newspaper writer says: "A short time since I heard a hard-working farmer say in all seriousness, 'I can't afford a sanitary barn, and if pushed shall have to go out of the milk 

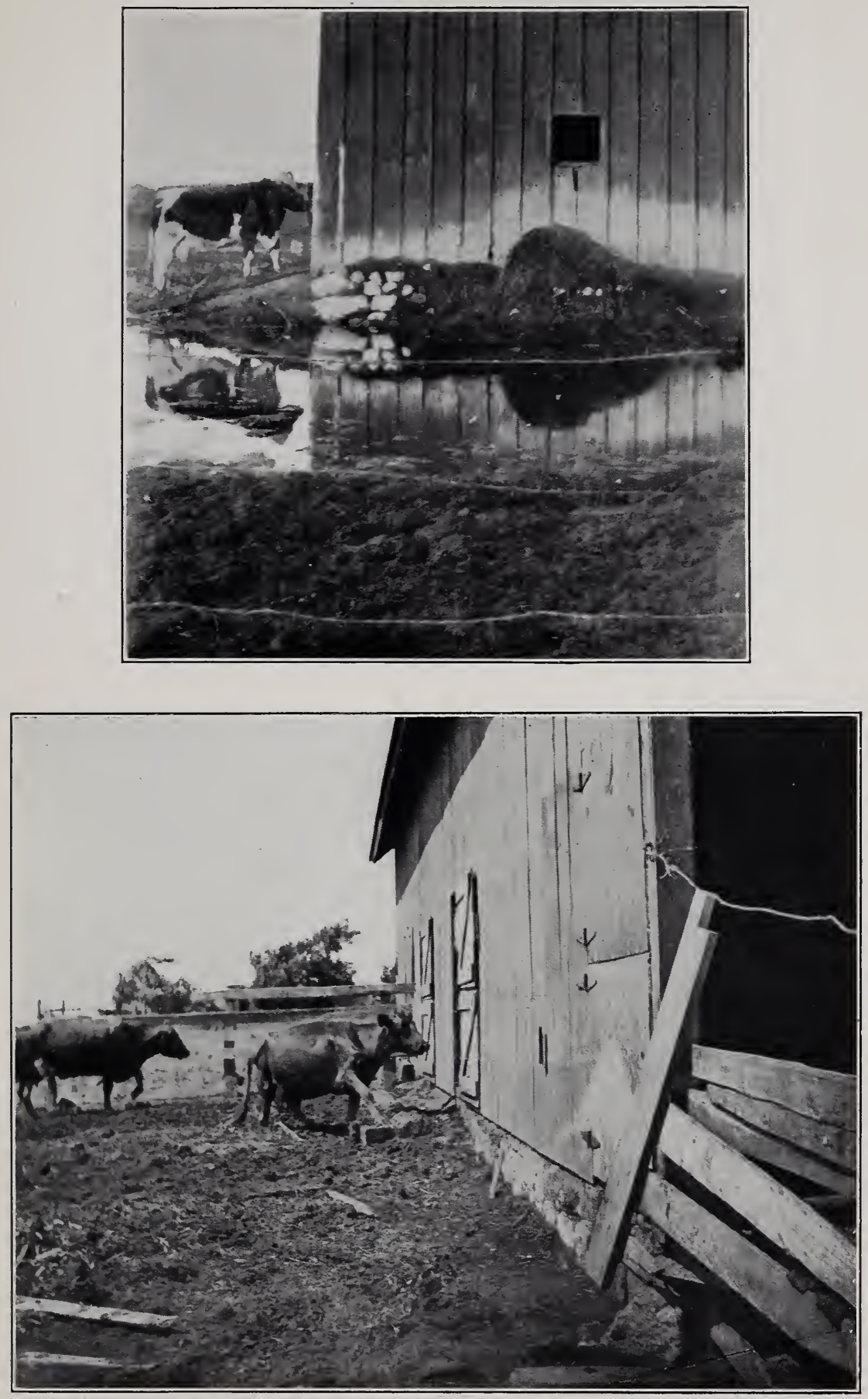

DIRTY BARNYARDS, WASTEFUl OF MANURE AND INCREASING EXPENSE OF KEEPING COWS CLEAN. 
Digitized by the Internet Archive in 2016

https://archive.org/details/extracostofprodu00wash 


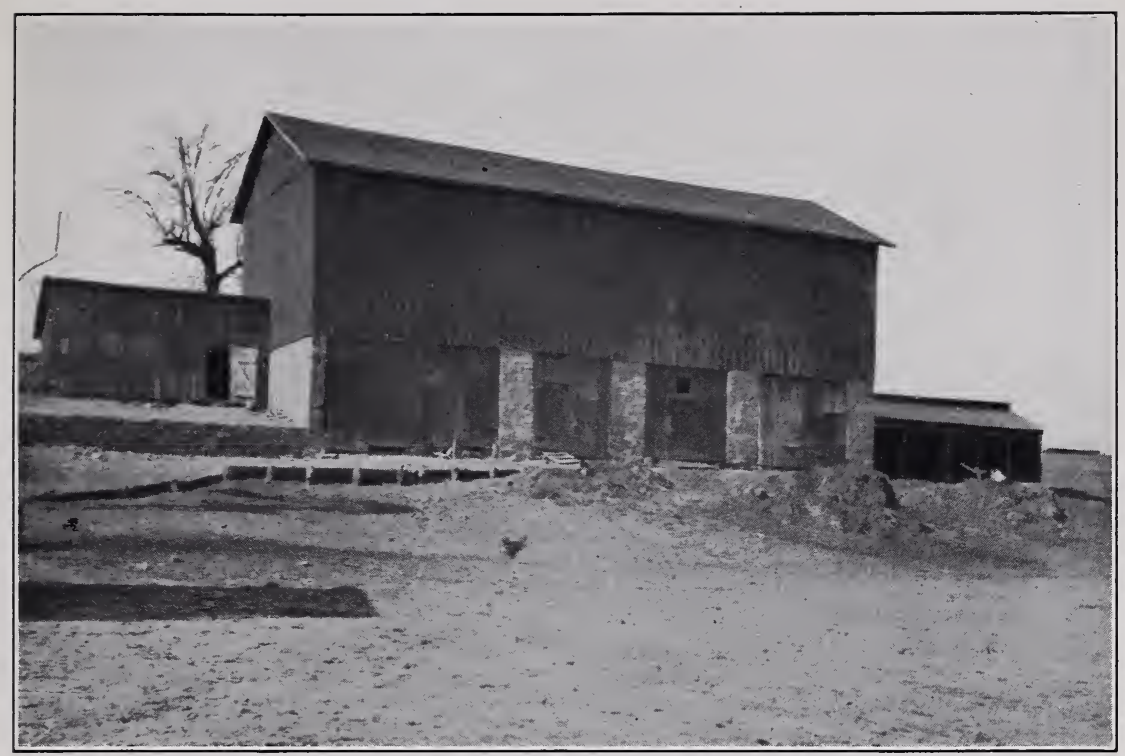

Fig. 1.-STABle With INSUfFicient Light and Ventilation.

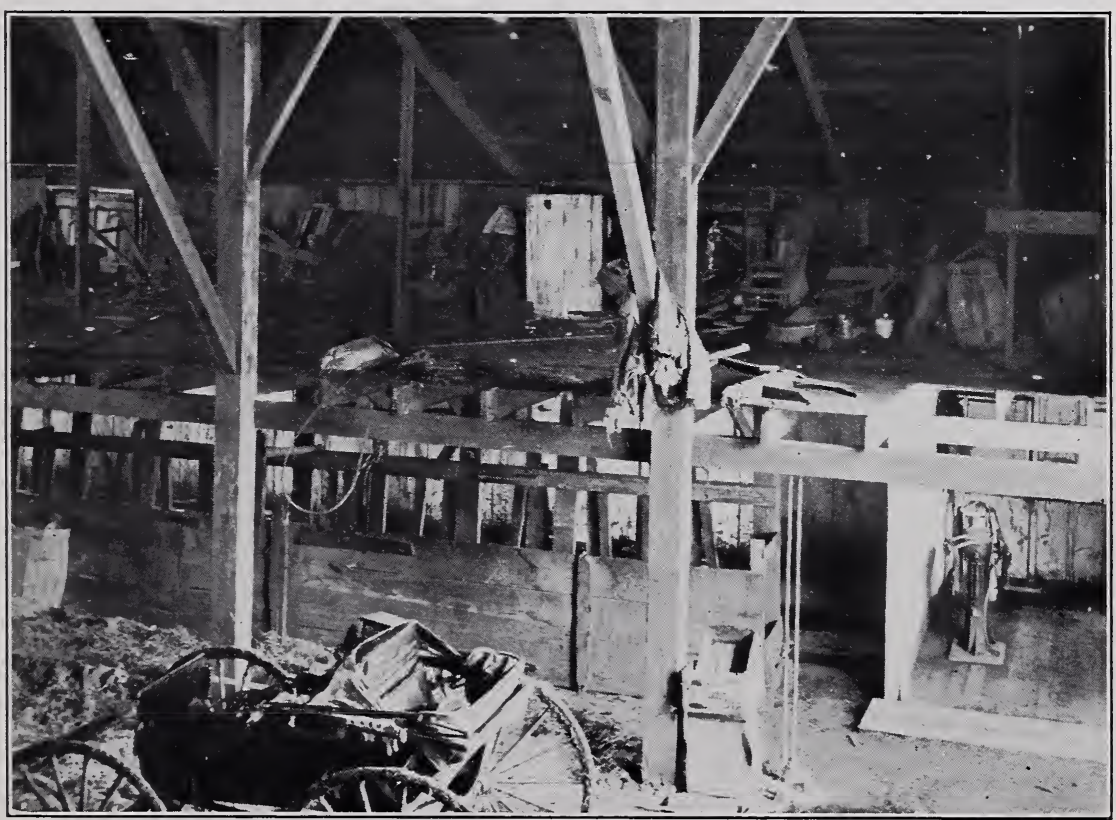

Fig. 2.-A Stable that is Difficult and Expensive to KeEp Clean. 



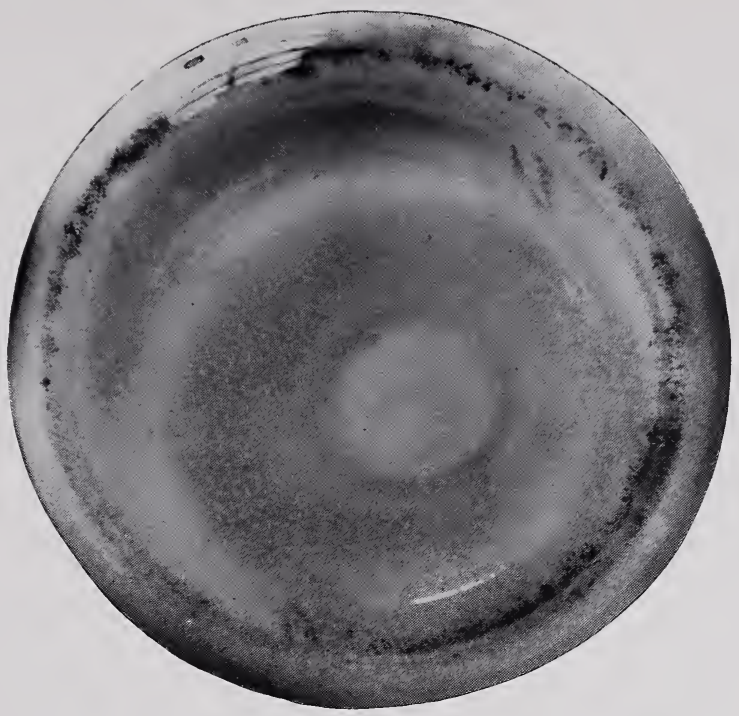

Fig. 1.-Sediment IN BotTom of Bottle of Milk. Such milk should not be regarded as merchantable.

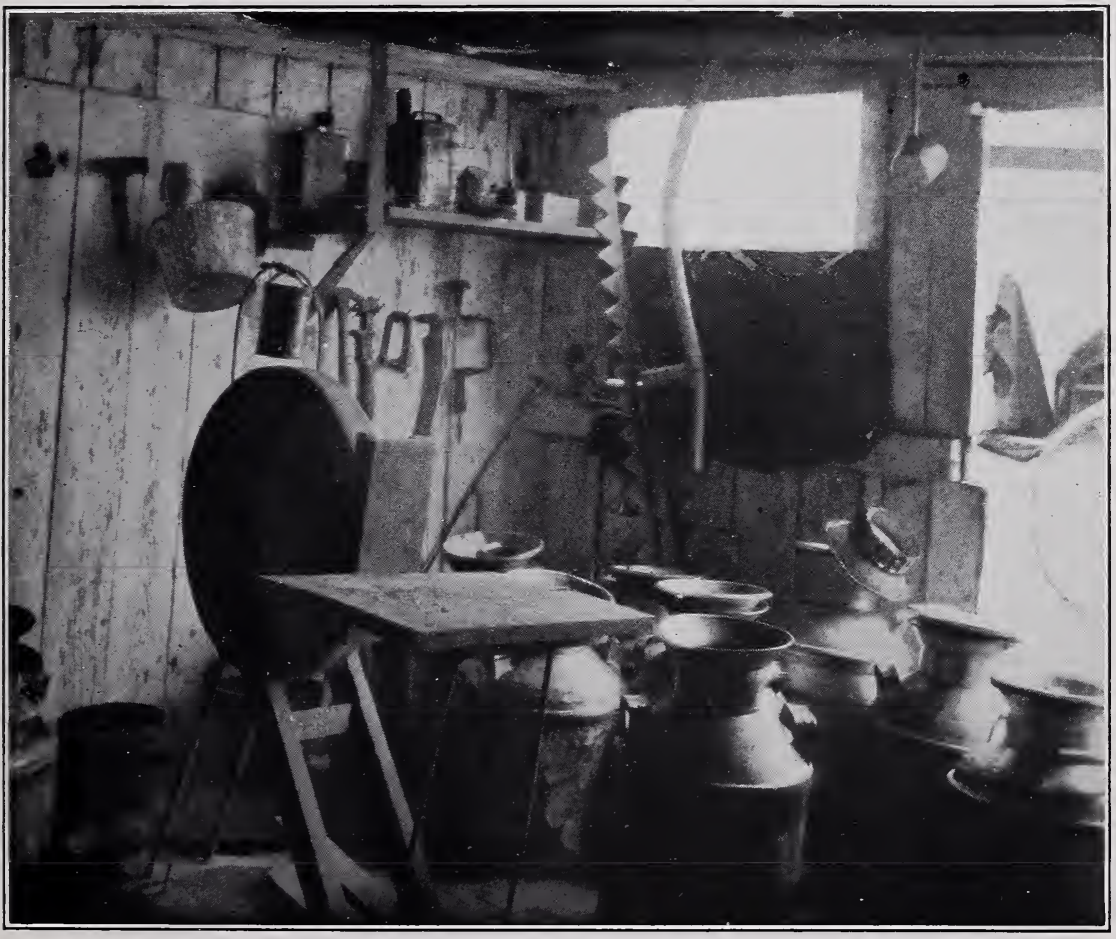

Fig. 2.-A Milk House favorable for DiRT and Odors.

To find a place somewhere else for a tool and paint room and for storage would not involve great expense. 



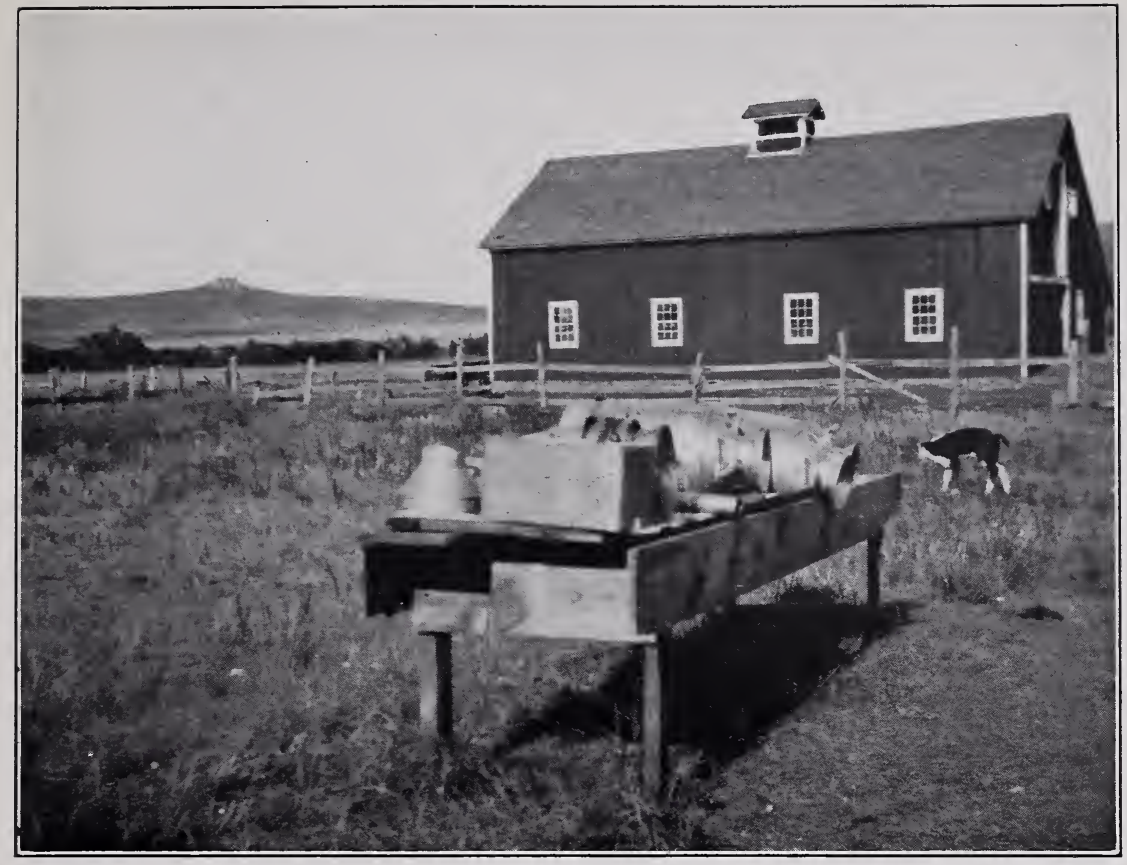

FIG. 1.-MILK CANS EXPOSED TO DIRT AND FLIES.

It costs nothing to invert cans so that dirt will not settle in them and to keep out flies. This dairy loses 3 points for improper care of cans.

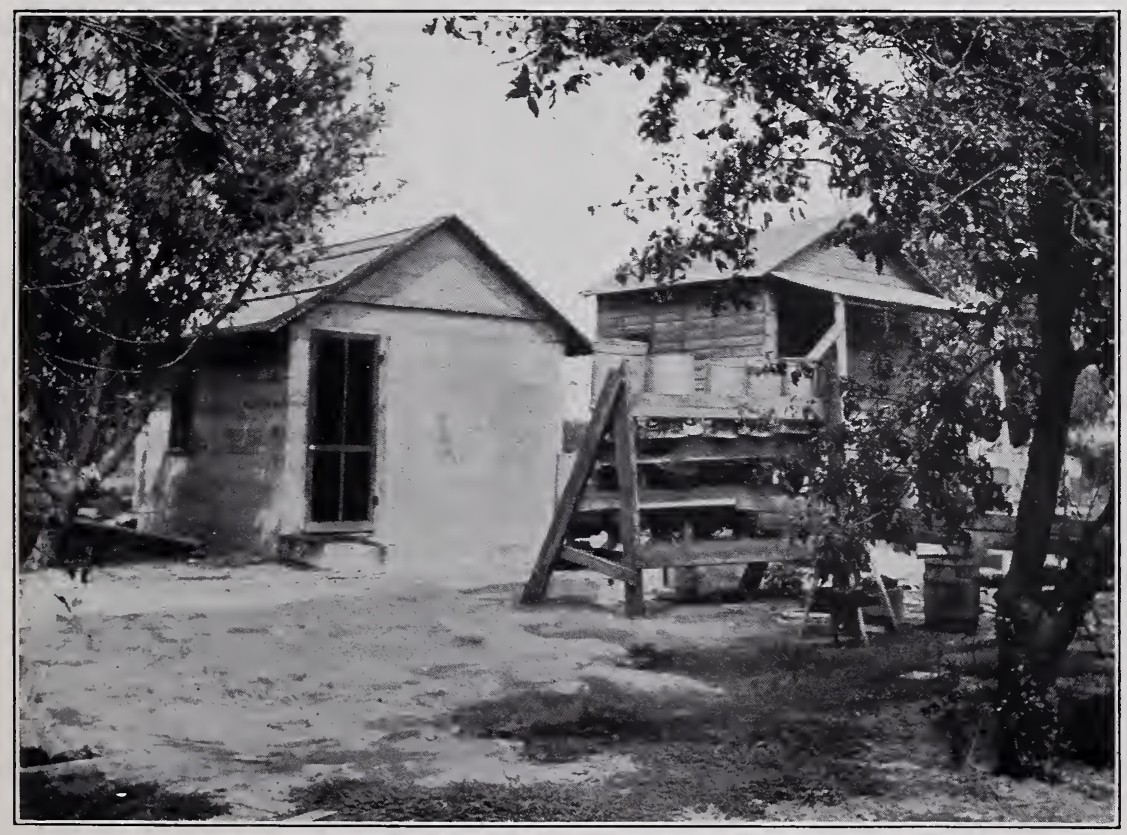

Fig. 2.-An INEXPENSIVE CEMENT MiLK House.

This house is not wholly completed. Observe milk cans inverted to dry. 

business." Says another writer: "In most cases more depends on the individual than upon the score of the barn." His statement is literally true, though liable to be misleading. The object of good barn conditions is not merely to get a creditable score simply for the score's sake, but to help the individual in his efforts to produce clean milk and to have a healthy herd. A man who is exceptionally painstaking in his methods can get a good total score even when allowed nothing for the barn, but its poor condition would be a handicap and would increase the cost of cleanliness and caring for the herd. In this case a better barn would be an economy.

To secure a properly drained site where the country is level and the buildings already constructed may require expensive grading and other changes, but this counts only 1 point, and in such cases it may be well to see if the expenditure can not be laid out more profitably in other directions. When the site of a barn is poorly drained a clean, well-drained yard is almost impossible, and will doubtless require some expense for cement or cinders, but the result will reduce the expense of keeping the cattle clean.

To secure freedom from contaminating surroundings will frequently add nothing to the expense account, though sometimes it may mean a new place for the swine so that the incident odors and flies may not injure the milk.

A tight and sound floor, smooth and tight walls and ceiling, a wide and deep gutter, a stanchion of the "swing" type simply supported, a simple partition for stalls, and a manger which is merely a concare depression in a cement floor, are recommended as a perfect form of stable construction, carrying 4 points. These recommendations are based on the fact that a stable so constructed has a minimum of dirt-catching possibilities, and saves labor if one is to produce clean milk. Still, as has been stated, a good total score can be made by extra care when the equipment is inferior. But when the floor becomes rotten and urine-saturated, nothing can be done except to incur the expense of a new floor, preferably of cement. To offset this a tight floor will frequently pay a liberal profit on the investment in the saving of fertilizer, and hence be no burden on the producer.

A rell-drained site for the barn, free from contaminating surroundings, with enough space for the cors, and proper floor, walls, ceiling, stanchions, etc., counts 9 points. But proper conditions in these respects will also help the score under the heading of cleanliness. A location poorly drained will usually have a dirty barnyard ( 2 points), which may be so bad as to contaminate the stable air, causing the loss of a point or two more; and this may also mean dirty corrs. A rotten, soaked floor may be so filthy as to cause the loss of 2 points for cleanliness of floor and 2 more for stable air. Contaminating surroundings, such as pig pens or horses, may pollute 
the stable air, causing a loss of several points. Expense in rectifying these troubles may be necessary to get satisfactory conditions, but will help both the barn score and the score for methods.

As regards cleanliness of stable and air, we hare already assumed that half-good conditions should be charged to the mere fact of doing business. In some cases there will be slight expense for changes, so that horses may not be kept in the same room with the cows. With a stable so built as to facilitate economy of labor, threequarters of an hour a day will accomplish much in cleaning up and keeping clean. This is an average of three minutes for each cow in a 15-cow dairy. An average of even two minutes more a cow-thirty minutes a day-will keep the milk house reasonably clean.

\section{THE MILK ROOM.}

In the matter of the milk room some expense may be necessary. It has been the practice at some dairies where milk is sold by the can to have no milk room or milk house. The milk is strained from pail to carrier can in the barn and allowed to stand there in winter until the time to take it to the railroad station. In summer the can is set in the tank of water in the barnyard. The dairy utensils are washed with the domestic utensils in the kitchen. Where such a condition exists there will necessarily be expense for constructing a milk house. It need not be costly. Circular No. 158 of this Bureau gives plans for such a building, to cost from $\$ 200$ to $\$ 100$. The writer found a small cement milk house in Kansas which had cost the proprietor only $\$ 50$ for material, the labor having been performed by himself.

A milk room or milk house should have smooth and tight floor, walls, and ceilings, with ample light and rentilation, and be thoroughly screened against flies and other insects. It should be used only for milk purposes and in no case for storage, especially of clothing, horse blankets, harness, or anything of such nature. The expense of the best modern practice, so far as the milk house goes, will be very slight outside of the necessities of the construction of the building itself. Four points are allowed for construction and 3 for cleanliness.

UTENSILS, EQUIPMIENT, ETC.

The score card calls for facilities for washing and sterilizing the utensils in the milk house itself, not in the kitchen, and the practice of bringing hot water from the kitchen stove is not satisfactory. In some instances there must be an expense of from $\$ 10$ to $\$ 50$ for a heater to furnish the necessary hot water or steam.

A small-top milk pail will cost from $\$ 1.50$ to $\$ 3$, according to the pattern used; in some places a small-top cover for ordinary milk 
pails can be secured as low as 75 cents. If three or four pails are used, the added expense will range from $\$ 3$ to $\$ 12$.

A milk cooler is desirable for the best work, and will cost in the neighborhood of $\$ 15$, though where milk is sold by the can, fairly satisfactory results are obtained by setting the cans in a tank of cold water.

The added expense to each producer for new construction and equipment can not be estimated on account of varying conditions. In many cases it will be nothing, and in others it may vary from 75 cents for a small-top pail corer to $\$ 2,000$ or even more for a new stable and milk house. Where the barn is old and in bad condition.

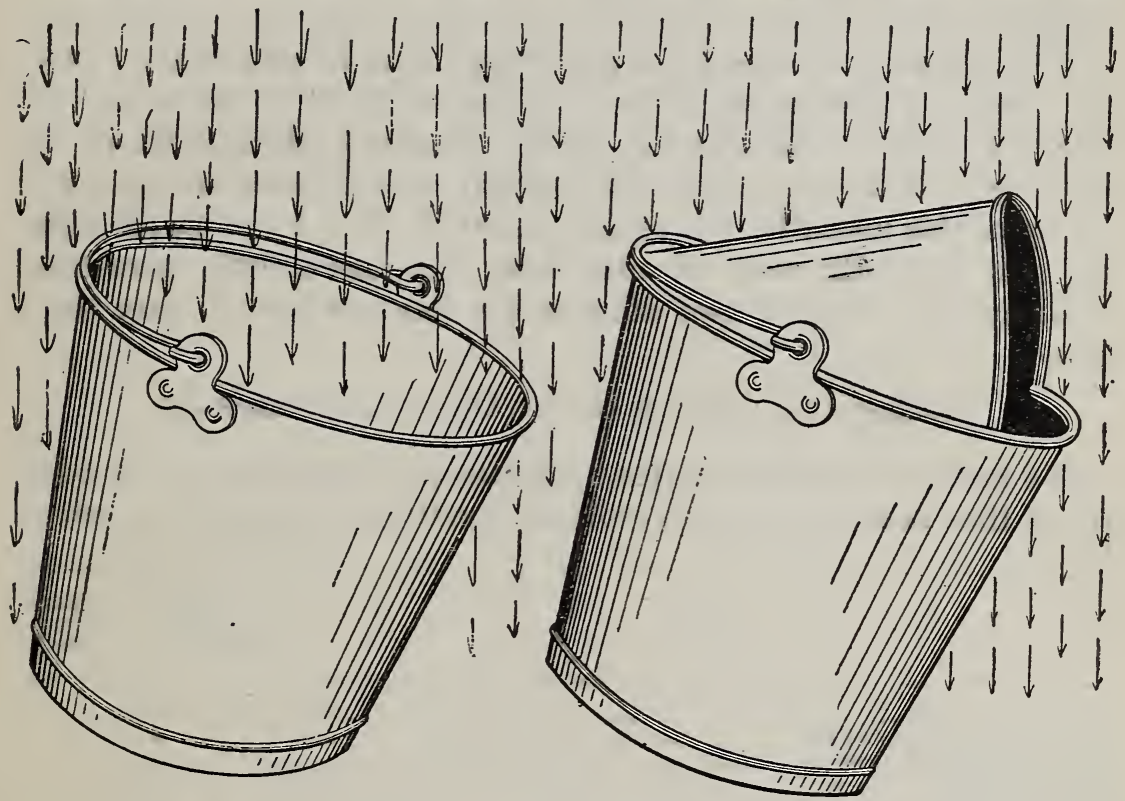

FIG. 3.-Open and hooded milk pails. A hooded pail will keep much dirt out of the milk. The hood can be put on by any competent tinsmith for a small price.

but well located, to make repairs upon it may be extravagance. To let it stand to be used for storage and to build a one-story cow stable as a wing may be advisable. If we assume the extreme of $\$ 2,000$ on construction account, 10 per cent a year for depreciation and 5 per cent a year for interest on investment will make an annual expense of $\$ 300$. This is $\$ 20$ per cow per year in a 15 -cow dairy, and less where more are kept. The number of farmers who ought to make a $\$ 2,000$ investment is comparatively small; for the average producer this figure would be excessive.

The cost of scalding utensils is chiefly caused by the investment for a heating apparatus. There may be a little additional expense for fuel. Scalding the utensils will add 2 points to the score already 
allowed, and will frequently cause a saving in losses from sour milk.

Wiping the udders with a dry cloth a few minutes before milking gives 1 point. Many producers waste time here. After sitting down to milk they wipe the udders with a dry cloth or with bare hands, raising a dust which settles into the milk and increases the contamination. Time has been wasted and the product is worse for the misdirected energy. The udders should be wiped long enough before milking to allow dust to settle. Wiping the udders with a moist cloth gives 4 points, while the added trouble of washing and drying the udders adds 2 points more. Two minutes per cow will gain the 4 points.

Two points are allowed for remoring the milk immediately from the stable as fast as each cow is milked. There is no excuse for allowing milk to stand in the stable, absorbing odors, until all the milking is done, and 1 point has already been allowed for part-way commendable methods. To remove the milk of each cow in the milking pail to a milk house or milk room may take a little extra time. Estimate this labor at two minutes per day per cow to gain the 1 point.

SUMMARY OF CONDITIONS INVOLVING ADDED EXPENSE.

We have now assumed fifteen minutes per cow daily as the additional time necessary to raise ordinary conditions, 16 points, as below:

\begin{tabular}{|c|c|c|}
\hline Item. & $\begin{array}{c}\text { Minutes } \\
\text { per day } \\
\text { per animal. }\end{array}$ & $\begin{array}{l}\text { Additional } \\
\text { points } \\
\text { gained. }\end{array}$ \\
\hline 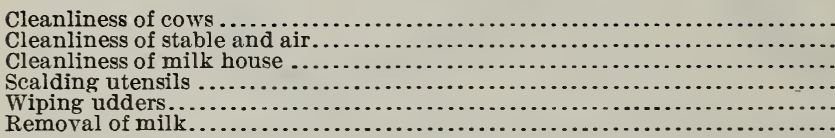 & $\begin{array}{l}5 \\
3 \\
2 \\
1 \\
2 \\
2\end{array}$ & $\begin{array}{l}3 \\
4 \\
2 \\
2 \\
4 \\
1\end{array}$ \\
\hline 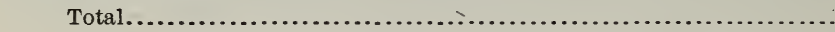 & 15 & 16 \\
\hline
\end{tabular}

We have assumed in the first part of this article that any dairyman should secure at least 42 points as the lowest score that could be considered as a necessary incident of doing business, and none of the expense of reaching this standing should be charged to the advanced teaching of modern bacteriology. A dairyman really ought to do much better than that before anything is said about the added burden of meeting up-to-date sanitary requirements. But let the figure stand at 42 for the sake of moderation and conservatism. We have now shown how an expenditure of fifteen minutes per day per cow in a 15-cow dairy will add 16 points to the score, bringing it up to 58. Estimating labor at 20 cents an hour. 5 cents a day per cow, in addition to the expense of ordinary conditions, will give a rating 
of 58. This includes nothing for cooling and storing milk and nothing for stable and milk room.

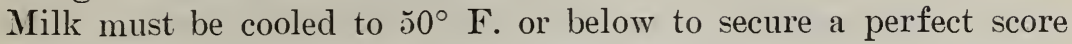
for efficient cooling, and when evening's milk is held for morning delivery it must be held at the same temperature to score perfect for storage. These 8 points, and 2 more for perfection in transportation, necessitate the use of ice. Spring water which would cool the milk below $60^{\circ} \mathrm{F}$. would raise the score from 58 to 61 , and would in most cases add nothing to the cost of production.

Should the use of ice be charged against the expense of modern bacteriology? In some parts of the South dairymen who retail their own product and have not been accustomed to use ice make two deliveries a day. Under such conditions the use of ice for the efficient cooling and proper storage of milk would be an economy instead of an added expense, for ice would be less expensive than the second delivery. In New England, New York, and some other States ice is regularly stored by the farmers and is regarded as necessary as the hay crop. In those States the use of ice adds nothing to existing expenses. It seems to the writer hardly reasonable to include the expense of ice in the "burden" of up-to-date milk production; but compromising on this by considering cooling to and storing at $55^{\circ} \mathrm{F}$., which carry 6 points instead of 8 , and the score is raised from 58 to 64. This has caused an added expense of 5 cents per cow per day, with as yet no allowance or estimate for construction of stable and milk house, small-top pails, cooler, etc., which give 18 points in all. If a producer gets one-third of this, or 6 , his total score will be 64 plus 6 , or 70 . The added expense of these 6 points will vary from nothing to the extreme expense of about $5 \frac{1}{2}$ cents per cow per day in a herd of 15 for new construction, repairs, and equipment.

One other item of added expense has never been noticed in the discussion of this subject. In the production of reasonably clean milk constant care is required-eternal vigilance is needed. It is only reasonable that the dairyman should have some compensation for this. As his product improves he is more and more of a careful, skilled workman, and he should therefore be better remunerated. There may be a wide variation of opinion as to the amount of this added compensation, but for the purpose of making an estimate we will place it at 5 cents per cow per day in a herd of 15 .

\section{GENERAL SUMIMARY.}

To sum up: To increase the score of a dairy from 42 to approximately 70 points there may be in 15 -cow dairies an added expense of 5 cents per cow per day for labor, plus, in extreme cases, $5 \frac{1}{2}$ cents for new

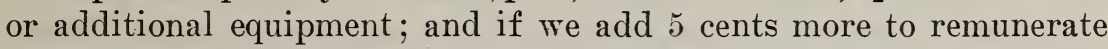
the proprietor for his extra care and vigilance there will be an extreme 
increase of $15 \frac{1}{2}$ cents per cow per day. The product of a cow ranges from 4,000 to 10,000 pounds of milk a year, or from 5 to 12 quarts a day. The added expense for labor would therefore amount to about half a cent to 1 cent a quart, and in the rare instances where great additional expense is required for repairs, new construction, and new equipment, this might raise the increase 1 to 2 cents a quart more. The allowance for extra remuneration to the dairyman for added care, which is usually not included in estimates of this kind, but which is considered in the business world in estimating what is reasonable as to salaries, would bring the total added expense per quart from $1 \frac{1}{2}$ cents when cows give large amounts of milk to 3 cents when the cows are of low production. The added actual labor and the remuneration for the proprietor-without any new construction or equipment-would increase the expense from 1 to 2 cents a quart. 'This added expense of improved methods and equipment, however, would no doubt be partly offset by increased production and increased economy of feed, so that the net extra expense of producing clean milk would probably be somewhat less than the figures given.

The writer has made no attempt to discuss, in a dogmatic way, the added expense of producing sanitary milk, but rather to offset the exaggerations and vague generalities which have been published about oppressive and unreasonable demands by specific statements concerning the various details of the dairy industry. In other words, the purpose of this paper is to show that while modern sanitary requirements are not as burdensome as has been represented in some quarters, yet high-grade milk does necessarily cost more than a mediocre product. We have not discussed the difference in actual cost between dirty and reasonably clean milk; that question, indeed, admits of no discussion. Dirty milk ought not to be considered a merchantable article at any price, no matter how low. Any mention of cost or selling price ought to presuppose milk that is at least halfway clean-say, such as would be produced in a dairy scoring in the vicinity of 50 .

The fact that there have been exaggerations of the demands and added expense of modern inspection is no argument against the consumer recognizing that the word "quality" as applied to milk means more than chemical composition, that there may be milks of widely varying quality even where the amount of milk solids is the same. A reasonably clean milk is worth 2 cents more than common slovenly milk. The former is safer and therefore cheaper at the increased price.

There has been too much indifference on the part of consumers regarding clean milk, too much of a tendency to regard all milk as the same, and too much of a desire to buy it at a low price, regardless of quality. Merely as a matter of sentiment and refinement, clean and 
fresh fruit and vegetables command a premium, while dirty food is frequently unsalable at any price. Milk, however, is often regarded with less discrimination. A little sediment meets with no emphatic disapproval. Consumers on seeing side-by-side pictures of bad and of sanitary stables comment favorably on the latter and express disapproval of a food produced in the former, but they haggle over the price and when it comes to paying the bills fail to recognize more value in one kind of milk than the other. Milk in most instances is consumed raw, and is exposed to the direct contamination of all the bad conditions with which it comes in contact. Furthermore, it is the exclusive diet of many invalids and infants, and is an almost perfect medium for the development and spread of germ diseases. Aside from any refined prejudices in favor of clean food, dirty milk may prove expensive even as a gift, while clean milk may be an economy at several cents above the ordinary price. The cheapest article is often the most extravagant. A few additional cents a quart for milk is cheap insurance against some forms of sickness. At the higher price the food material in the milk is cheaper than in many kinds of meat.

The propaganda for the production of cleaner milk must be accompanied by an educational campaign among consumers for a realization of the superior safety of the better article and an appreciation of its greater value, expressed in dollars and cents. 


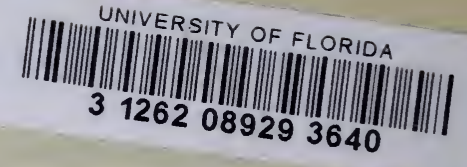

